\title{
ANALISIS FAKTOR - FAKTOR YANG MEMPENGARUHI KETAHANAN PANGAN RUMAH TANGGA PETANI (Studi Kasus : Desa Timbulharjo, Sewon, Bantul)
}

\author{
Vizia Lukri Damayanti, Rifki Khoirudin \\ Fakultas Ekonomi \& Bisnis, Universitas Ahmad Dahlan \\ Jl. Kapas No. 9, Semaki, Umbulharjo, Yogyakarta \\ Email Korespondensi: vizialukrid@yahoo.co.id \\ Naskah Diterima: Juni 2016; Disetujui: Oktober 2016
}

\begin{abstract}
This study aims to determine the factors that affect food security of farm households in Timbulharjo Village, Sewon, Bantul. Factors used in this study were income, head of family education, age of head of household, marital status, number of family members and ownership of savings account. This study uses primary data obtained from direct interviews by asking a list of questions. The analytical technique used was logistic regression analysis, then completed by using the maximum likelihood method which included Nagelkerke $R$ Square equivalent to coefficient of determination (R2), significance test Simultaneously (Overall Model Test) is equivalent to F test in linear regression, Wald test is equivalent to $t$ test on OLS. The income and education of the head of the household have a positive effect on food security, while the number of family members has a negative effect on food security. Based on the partial test, the income variable, the education of the head of the household, the number of family members affect the food security, while the age of the head of the family, marital status, and savings ownership have no effect on food security.
\end{abstract}

Keywords: food security, farm household

JEL Classifications: D1, D3

\begin{abstract}
Abstrak: Penelitian ini bertujuan untuk mengetahui faktor-faktor yang mempengaruhi ketahanan pangan rumah tangga petani di Desa Timbulharjo, Sewon, Bantul. Faktor yang digunakan dalam penelitian ini adalah pendapatan, pendidikan kepala keluarga, usia kepala keluarga, status perkawinan, jumlah anggota keluarga dan kepemilikan simpanan tabungan. Penelitian ini menggunakan data primer yang diperoleh dari wawancara langsung dengan mengajukan daftar pertanyaan. Data yang digunakan yaitu 98 sampel secara insidental dari 4.628 petani di Desa Timbulharjo, Sewon, Bantul. Teknik analisis yang digunakan adalah analisis regresi logistik, selanjutnya diselesaikan dengan menggunakan metode maximum likelihood yang meliputi Nagelkerke $R$ Square setara dengan koefisien determinasi $\left(R^{2}\right)$, Pengujian signifikansi secara simultan (Overall Model Test) setara dengan uji F dalam regresi linier, Uji Wald setara dengan uji t pada OLS. Hasil penelitian menunjukan bahwa pendapatan, pendidikan kepala keluarga dan jumlah anggota keluarga berpengaruh terhadap ketahanan pangan dengan tingkat signifikansi 5\%. Nilai Nagekerke $R$ Square 0,363. Pendapatan dan pendidikan kepala keluarga berpengaruh positif terhadap ketahanan pangan, sedangkan jumlah anggota keluarga berpengaruh negatif terhadap ketahanan pangan. Berdasarkan uji parsial maka variabel pendapatan, pendidikan kepala keluarga, jumlah anggota keluarga berpengaruh terhadap ketahanan pangan, sedangkan usia kepala keluarga, status perkawinan, dan kepemilikan tabungan tidak berpengaruh terhadap ketahanan pangan.
\end{abstract}

Kata kunci: ketahanan pangan, rumah tangga petani

Klasifikasi JEL: D1, D3 


\section{PENDAHULUAN}

Ketahanan Pangan merupakan hak asasi manusia (HAM). Setiap orang berhak memperoleh makanan yang layak dan sesuai dengan kebutuhannya. Berdasarkan UndangUndang No 18 tahun 2012, yang dimaksud dengan ketahanan pangan adalah "kondisi terpenuhinya pangan bagi negara sampai dengan perseorangan, yang tercermin dari tersedianya pangan yang cukup, baik jumlah maupun mutunya, aman, beragam, bergizi, merata, dan terjangkau serta tidak bertentangan dengan agama, keyakinan, dan budaya masyarakat, untuk dapat hidup sehat, aktif, dan produktif secara berkelanjutan."

Pertanian merupakan sektor terpenting sebagai penopang untuk memenuhi kebutuhan hidup orang banyak, khususnya kebutuhan hidup makanan pokok manusia sebagai wujud peningkatan kesejahteraan bangsa dan negara. Kabupaten Bantul merupakan salah satu daerah lumbung pangan yang potensial di Daerah Istimewa Yogyakarta (DIY), khususnya produksi tanaman padi. Luas Lahan Sawah Kabupaten Bantul pada tahun 2014 menurut Dinas Pertanian dan Kehutanan tercatat 15.191 Ha, Pada tahun 2014 produksi tanaman padi sawah tercatat 192.711 ton dengan rata-rata produksi sebesar $63,90 \mathrm{kw} / \mathrm{ha}$, produksi tanaman padi ladang 136 ton dengan rata-rata produksi $45,25 \mathrm{kw} / \mathrm{ha}$. Selain produksi padi, Kabupaten Bantul juga dapat memproduksi bahan pangan lain seperti jagung, kacang tanah, kedelai maupun berbagai produk pertanian lainnya.

Sektor pertanian merupakan penyumbang terbesar perekonomian di Kabupaten Bantul terutama produksi tanaman pangan (padi dan palawija). Tanaman padi sawah merupakan komoditas terbesar di Kecamatan Sewon. Berdasarkan data kependudukan 2016 jumlah penduduk Bantul produktif menurut jenis pekerjaan (Usia Angkatan Kerja) Kecamatan Sewon merupakan Kecamatan dengan penduduk terbanyak yang bekerja sebagai petani di Kabupaten Bantul . Jumlah penduduk Sewon yang berkerja sebagai petani sebanyak 15.166 orang atau $11,07 \%$ dari jumlah total petani di Kabupaten Bantul 136.919 orang.

Desa Timbulharjo merupakan salah satu Desa yang ada di Kecamatan Sewon, Desa tersebut memiliki letak topografis tanah yang rata, sebagian besar lahannya dimanfaatkan oleh masyarakat untuk lahan pertanian, sehingga sebagian besar masyarakat Desa adalah petani. Jumlah penduduk Desa Timbulharjo yang bekerja sebagai petani adalah 4.628 orang atau $30,51 \%$ dari 15.166 orang yang terdiri dari 2.523 petani laki-laki dan 2.105 petani perempuan. Desa Timbulharjo merupakan Desa dengan jumlah petani terbanyak di Kecamatan Sewon.

Beberapa penelitian sebelumnya menyebutkan bahwa terdapat beberapa faktor yang mempengaruhi ketahanan pangan suatu daerah. Faktor yang paling berpengaruh terhadap ketahanan pangan rumah tangga adalah jumlah anggota keluarga dan pengeluaran RT. Penelitian yang dilakukan oleh Sulistyowati (2014) tentang faktor yang mempengaruhi ketahanan pangan rumah tangga miskin di Kecamatan Srandakan Bantul menyatakan bahwa faktor jenis kelamin dan jenis pekerjaan tidak berpengaruh terhadap tingkat ketahanan pangan. Adapun faktor yang dapat mempengaruhi ketahanan pangan RTM di Srandakan antara lain umur kepala RTM, status perkawinan, jumlah anggota keluarga dan pendapatan. Dan faktor yang paling dominan mempengaruhi ketahanan pangan RTM yaitu jumlah anggota keluarga dan pendapatan rumah tangga.

Supriyanto (2014) menyatakan bahwa faktor pendapatan kepala keluarga dan tingkat pendidikan berpengaruh positif terhadap ketahanan pangan, sedangkan kemampuan memenuhi kebutuhan keuangan (simpanan) berpengaruh negatif tehadap tingkat ketahanan pangan. Jumlah anggota keluarga, umur kepala keluarga tidak mempengaruhi tingkat ketahanan pangan rumah tangga tani. 


\section{METODE PENELITIAN}

\section{Populasi dan Sampel}

Populasi dalam penelitian ini adalah rumah tangga petani yang ada di Desa Timbulharjo, Sewon, Bantul. Adapun jumlah petani di Desa Timbulharjo sebanyak 4.628 orang petani yang terbagi dalam 16 Dusun dengan 123 Rukun Tetangga (RT). Jadi jumlah populasi dalam penelitian ini ada 4.628 petani. Penentuan sampel dalam penelitian ini dihitung dengan rumus Slovin (Hasan, 2000) sebagai berikut:

$$
\mathrm{n}=\frac{N}{1+N(e)^{2}}
$$

Keterangan :

$\mathrm{n}=$ ukuran sampel

$\mathrm{N}=$ ukuran populasi

$\mathrm{e}=$ error term (variabel pengganggu)

ketidaktelitian karena kesalahan pengambilan sampel yang dapat ditolelir atau diujikan.

Penelitian ini menggunakan tingkat kesalahan yang ditolerir $10 \%$.

$$
\begin{gathered}
\mathrm{n}=\frac{4.628}{1+4.628(0,1)^{2}} \\
\mathrm{n}=98
\end{gathered}
$$

Berdasarkan perhitungan Slovin, maka jumlah sampel dalam penelitian ini sejumlah 98 responden.

\section{Jenis Data Dan Sumber Data}

Data yang digunakan dalam penelitian ini diantaranya adalah :

(1) Data Primer; Data primer yang diperoleh dengan memberikan kuesioner yang ditujukan kepada responden (rumah tangga petani di Desa Timbulharjo, Sewon, Bantul) meliputi pengeluaran pangan dan non pangan rumah tangga, pendapatan, jumlah anggota keluarga, umur kepala keluarga, pendidikan kepala keluarga, status perkawinan. Tujuannya untuk memperoleh informasi yang relevan dalam penelitian ini.

(2) Data Sekunder; Data sekunder merupakan sumber penelitian yang diperoleh secara tidak langsung. Data diperoleh dengan mengumpulkan data-data yang ada di Biro Pusat Statistik (BPS) Kabupaten Bantul dan monografi data kelurahan. Data yang diambil merupakan data mengenai rumah tangga petani sebagai suatu penelitian empiris, maka datadata sekunder dalam penelitian ini juga dapat diperoleh dari artikel, jurnal, dan penelitianpenelitian terdahulu yang berkaitan dengan tingkat ketahanan pangan rumah tangga petani.

\section{Teknik Pengumpulan Data}

1. Metode Wawancara (Interview)

Penelitian ini menggunakan metode interview secara terstruktur menggunakan panduan kuesioner (angket) sebagai panduan utama. Dalam metode ini digunakan untuk membantu menjelaskan kepada responden apabila responden kurang jelas dalam menjawab angket.

2. Metode Kuesioner (Angket)

Kuesioner merupakan teknik pengumpulan data yang dilakukan dengan cara memberi seperangkat pertanyaan atau pernyataan tertulis kepada responden untuk dijawab. Kuesioner merupakan teknik pengumpulan data yang efisien bila peneliti tahu dengan pasti variabel yang akan diukur dan tahu apa yang bisa diharapkan dari responden (Sugiyono, 2009).

\section{Alat Analisis Data}

Metode analisis data dalam penelitian ini menggunakan teknik analisis kuantitatif. Analisis kuantitatif dilakukan dengan cara menganalisis permasalahan yang diwujudkan dengan data yang dapat dijelaskan secara kuantitatif. Metode analisis yang digunakan dalam penelitian ini adalah analisis regresi logistik.

Logistic regresi merupakan teknik statistik yang tepat ketika variabel dependen berbentuk diskret atau kategorial (non-metrik) dan variabel independennya dapat berbentuk metrik atau non-metrik. Dengan kata lain logistic regresi merupakan pendekatan model matematika yang dapat digunakan untuk 
menggambarkan hubungan dari beberapa $X$ variabel untuk sebuah dikotomi dependen variabel.

Pada logistic regresi tidak mensyaratkan banyak asumsi seperti normalitas data serta hasilnya tetap robust walaupun ada asumsi yang dilanggar. Jika kita hanya ingin memprediksi dua kategorial dependen variabel maka analisis ini disebut binary logistic variabel, tapi jika kita ingin memprediksi lebih dari dua kategori dependen variabel maka kita harus menggunakan analisis multnominal logistic regresi.

\section{HASIL DAN PEMBAHASAN}

\section{Uji Kelayakan Model (Goodness of Fit Test)}

Tabel 1. Hosmer and Lemeshow Test

\begin{tabular}{cccl}
\hline Step & Chi-square & Df & Sig. \\
\hline 1 & 6.906 & 8 & 0.547
\end{tabular}

Sumber : Hasil Output SPSS 16

Hipotesis :

Ho: Model telah cukup mampu menjelaskan data/sesuai

Ha: Model tidak cukup mampu menjelaskan data

Terlihat dari tabel bahwa nilai sig $=0,547$ yang berarti lebih dari 0,05 maka keputusanya adalah menerima Ho sehingga kesimpulanya adalah model telah cukup mampu menjelaskan data sesuai dengan kata lain model dinyatakan layak atau fit untuk digunakan analisis selanjutnya.

\section{Pengujian Koefisien Determinasi (Nagelkerke R Square)}

Hasil output estimasi dapat dilihat pada tabel 2. Untuk melihat kemampuan variabel independen dalam menjelaskan variabel dependen, digunakan nilai Cox $\mathcal{E}$ Snell $R$ Square dan Nagelkerke $R$ Square. Nilai-nilai tersebut disebut juga dengan Pseudeo $R$ Square atau jika pada regresi (OLS) lebih dikenal dengan istilah $R$ Square.
Tabel 2. Pengujian Koefisien Determinasi

(Nagelkerke R Square Model Summary)

\begin{tabular}{cccc}
\hline Step & $\begin{array}{c}-2 \text { Log } \\
\text { likelihood }\end{array}$ & $\begin{array}{c}\text { Cox E } \\
\text { Snell } R \\
\text { Square }\end{array}$ & $\begin{array}{c}\text { Nagelkerke R } \\
\text { Square }\end{array}$ \\
\hline 1 & $103.000^{a}$ & .270 & .363
\end{tabular}

$a=$ estimation terminated at iteration number 5 because parameter estimates changed by less than ,001.

Sumber : Hasil Output SPSS 16

Nilai Nagelkerke R Square sebesar 0,363 yang menunjukan bahwa kemampuan variabel independen dalam menjelaskan variabel dependen adalah sebesar 0,363 atau 36,3\% dan terdapat $100 \%-36,3 \%=63,7 \%$ faktor lain di luar model yang menjelaskan variabel dependen.

Variabel pendapatan, pendidikan kepala keluarga, usia kepala keluarga, status perkawinan, jumlah anggota keluarga dan kepemilikan simpanan tabungan dapat menjelaskan ketahanan pangan sebesar 36,3\% sisanya dijelaskan di luar model.

\section{Pengujian Presentase Ketepatan Model Penelitian}

Berdasarkan tabel pengujian presentase ketepatan model penelitian pada Classification Table, jumlah sampel yang tidak tahan pangan $47+9=56$ orang. Yang benar-benar tidak tahan pangan sebanyak 47 orang dan yang seharusnya tidak mengalami tidak tahan pangan namun justru mengalami sebanyak 9 orang. Jumlah sampel yang tahan pangan $14+$ $28=42$ orang. Yang benar-benar tahan pangan sebanyak 14 orang dan yang seharusnya tahan pangan tetapi tidak mengalaminya sebanyak 28 orang.

Tabel 3. Pengujian Presentase Ketepatan Model Penelitian

Classification Table ${ }^{a}$

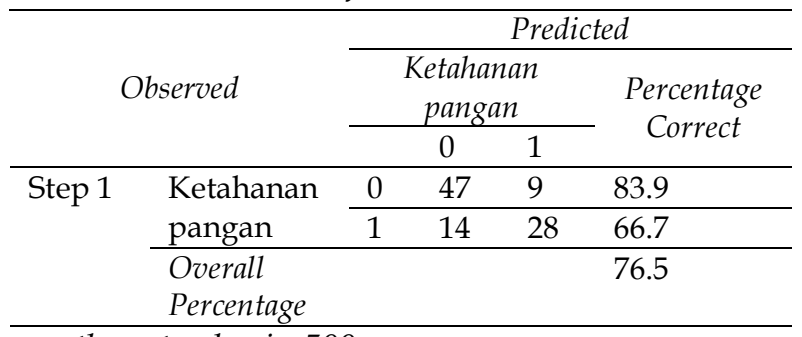

$a=$ the cut value is, 500

Sumber : Hasil Output SPSS 16 
Dalam interprestasi regresi logistik dengan SPSS: tabel di atas memberikan nilai overall percentage sebesar $(47+28) / 98=76,5 \%$ yang berarti ketapatan model penelitian ini adalah sebesar $76,5 \%$.

\section{Uji Simultan}

Tabel 4. Uji Simultan (Overall Test) Omnibus Test of Model Coefficients

\begin{tabular}{lllll}
\hline & & Chi-square & Df & Sig. \\
\hline Step 1 & Step & 30.850 & 6 & .000 \\
\hline & Block & 30.850 & 6 & .000 \\
\hline & Model & 30.850 & 6 & .000 \\
\hline
\end{tabular}

Sumber : Hasil Output SPSS 16

Hipotesis :

Ho: Tidak ada pengaruh signifikan secara simultan pendapatan, pendidikan kepala keluarga, usia kepala keluarga, status perkawinan, jumlah anggota keluarga dan kepemilikan simpanan tabungan terhadap ketahanan pangan.

Ha: Ada pengaruh signifikan secara simultan pendapatan, pendidikan kepala keluarga, usia kepala keluarga, status perkawinan, jumlah anggota keluarga dan kepemilikan simpanan tabungan terhadap ketahanan pangan.

Nilai p-value Chi-Square sebesar 0,000 di mana alpha $<0,05$ maka Ho ditolak sehingga jawaban terhadap hipotesis pengaruh simultan variabel independen terhadap variabel dependen. Kesimpulanya adalah ada pengaruh signifikan secara pendapatan, pendidikan kepala keluarga, usia kepala keluarga, status perkawinan, jumlah anggota keluarga dan kepemilikan simpanan tabungan terhadap ketahanan pangan.

\section{Uji Parsial}

Tabel 5. Uji Parsial

Variables in The Equations

\begin{tabular}{llllllll}
\hline & & B & S.E. & Wald & Df & Sig. & Exp(B) \\
\hline Step $1^{a}$ & Pendapatan & .000 & .000 & 7.864 & 1 & .005 & 1.000 \\
\hline & Pendidikan_KK & .743 & .302 & 6.005 & 1 & .014 & 2.103 \\
\hline Usia_KK & -.003 & .025 & .017 & 1 & .896 & .997 \\
\hline Status_Perkawinan & 1.007 & .676 & 2.224 & 1 & .136 & 2.739 \\
\hline JAK & -.702 & .303 & 5.375 & 1 & .020 & .495 \\
\hline Simpanan_Tabungan & -.481 & .546 & .776 & 1 & .378 & .618 \\
\hline Constant & -1.361 & 1.949 & .488 & 1 & .485 & .256
\end{tabular}

a. Variable(s) entered on step 1: Pendapatan, Pendidikan_KK, Usia_KK, Status Perkawinan, JAK, Simpanan_Tabungan, Constant.

Sumber : Hasil Output SPSS 16

\section{a. Pendapatan $(\mathrm{X} 1)$}

Hipotesis :

Ho: Tidak ada pengaruh pendapatan terhadap ketahanan pangan

Ha: Ada pengaruh pendapatan terhadap ketahanan pangan

Dari hasil analisis variabel pendapatan nilai signifikansi sebesar $0,005<0,05$ sehingga menolak Ho, sehingga ada pengaruh pendapatan terhadap tingkat ketahanan pangan rumah tangga petani di Desa Timbulharjo, Sewon, Bantul. Hal tersebut menunjukan bahwa kenaikan pendapatan diikuti dengan ketahanan pangan meskipun kemungkinan peningkatan probabilitas pendapatan hanya sebesar $0,00 \%$.

Hasil penelitian ini sejalan dengan hasil penelitian yang diperoleh oleh (Supriyanto, 2014) yang menyatakan bahwa pendapatan mempunyai pengaruh positif terhadap peluang rumah tangga petani untuk tahan pangan dengan menganggap variabel lain konstan.

\section{b. Pendidikan Kepala Keluarga (X2)}

Hipotesis :

Ho: Tidak ada pengaruh pendidikan kepala keluarga terhadap ketahanan pangan.

Ha: Ada pengaruh pendidikan kepala keluarga terhadap ketahanan pangan. 
Dari hasil analisis variabel pendidikan kepala keluarga nilai signifikansi sebesar 0,014 $<0,05$ sehingga menolak Ho, sehingga ada pengaruh pendidikan kepala keluarga terhadap tingkat ketahanan pangan rumah tangga petani di Desa Timbulharjo, Sewon, Bantul.

Hal tersebut menunjukkan bahwa semakin tinggi tingkatan pendidikan kepala keluarga diikuti dengan ketahanan pangan. Hasil penelitian ini sejalan dengan hasil penelitian yang diperoleh oleh (Supriyanto, 2014) yang menyatakan bahwa pendidikan kepala keluarga mempunyai pengaruh positif terhadap peluang rumah tangga petani untuk tahan pangan dengan menganggap variabel lain konstan.

\section{c. Usia Kepala Keluarga (X3)}

Hipotesis :

Ho: Tidak ada pengaruh usia kepala keluarga terhadap ketahanan pangan.

Ha: Ada pengaruh usia kepala keluarga terhadap ketahanan pangan.

Dari hasil analisis variabel usia kepala keluarga nilai signifikansi sebesar 0,896>0,05 sehingga menerima Ho, sehingga tidak ada pengaruh usia kepala keluarga terhadap tingkat ketahanan pangan rumah tangga petani di Desa Timbulharjo, Sewon, Bantul.

Hasil penelitian ini sejalan dengan hasil penelitian yang diperoleh oleh (Sulistyowati, 2014) yang menyatakan bahwa usia kepala keluarga tidak mempunyai pengaruh terhadap peluang rumah tangga petani untuk tahan pangan. Hal tersebut terjadi karena sebagian besar responden (petani) berusia inproduktif atau telah berusia $>65$ tahun, sedangkan usia seseorang dapat mempengaruhi produktivitas dalam bekerja. Semakin tua umur seseorang, maka produktivitaspun semakin menurun. Hal itu karena kekuatan fisik yang ada tidak sekuat sewaktu seseorang itu masih muda.

\section{d. Status Perkawinan (X4)}

Hipotesis :
Ho: Tidak ada pengaruh status perkawinan terhadap ketahanan pangan.

Ha: Ada pengaruh status perkawinan terhadap ketahanan pangan.

Dari hasil analisis variabel status perkawinan nilai signifikansi sebesar 0,136>0,05 sehingga menerima Ho. Sehingga, tidak ada pengaruh status perkawinan terhadap tingkat ketahanan pangan rumah tangga petani di Desa Timbulharjo, Sewon, Bantul.

Hasil penelitian ini berbeda dengan hasil penelitian yang diperoleh oleh (Sulistyowati, 2014) yang menyatakan bahwa status perkawinan mempunyai pengaruh terhadap peluang rumah tangga petani untuk tahan pangan. Perbedaan tersebut terjadi karena pada penelitian (Sulistyowati, 2014) didominasi rumah tangga yang berstatus nikah. Penelitian tersebut menyatakan bahwa rumah tangga yang berstatus nikah lebih tahan pangan dikarenakan dengan status nikah, maka suami istri tersebut bisa bekerjasama untuk memenuhi kebutuhan pangan sehari-hari.

Berbeda dengan penelitian ini karena dalam penelitian ini membahas mengenai rumah tangga petani yang pendapatannya tidak menentu tergantung iklim, hasil panen, dan faktor lainya. Meskipun hasil pengujian signifikansi 0,136>0,05 berarti bahwa tidak signifikan atau tidak ada pengaruh antara status perkawinan dengan ketahanan pangan, akan tetapi hasil pengujian dari hipotesis menunjukan positif. Hal ini terjadi karena meskipun rumah tangga petani berstatus menikah, akan tetapi penghasilan yang diperoleh oleh suami/istri petani tersebut tidak banyak, sehingga meskipun suami istri bekerjasama untuk memenuhi kebutuhan pangan sehari-hari masih belum mencukupi dikarenakan pengeluaran yang dikeluarkan tidak sebanding dengan pendapatan yang diperoleh. Selain itu juga beberapa istri petani di Desa Timbulharjo tidak bekerja dan menjadi ibu rumah tangga. 


\section{e. Jumlah Anggota Keluarga (X5)}

Hipotesis :

Ho: Tidak ada pengaruh jumlah anggota keluarga terhadap ketahanan pangan.

Ha: Ada pengaruh jumlah anggota keluarga terhadap ketahanan pangan.

Dari hasil analisis variabel jumlah anggota keluarga nilai signifikansi sebesar $0,020<0,05$ sehingga menolak Ho. Sehingga, ada pengaruh jumlah anggota keluarga terhadap tingkat ketahanan pangan rumah tangga petani di Desa Timbulharjo, Sewon, Bantul.

Jumlah anggota keluarga mempunyai pengaruh yang beragam, di satu sisi jumlah anggota keluarga menurunkan ketahanan pangan karena semakin banyak anggota keluarga dianggap akan menambah beban keluarga dalam memenuhi kebutuhan pangan (Pratiwi, 2016). Namun di sisi lain jumlah keluarga akan meningkatkan ketahanan pangan, karena banyaknya jumlah keluarga memungkinkan banyaknya anggota keluarga yang bekerja, sehingga dapat meningkatkan ketahanan pangan (Susilowati, 2014).

Hasil penelitian ini sejalan dengan hasil penelitian yang diperoleh oleh (Pratiwi, 2016) yang menyatakan bahwa jumlah anggota keluarga mempunyai pengaruh negatif terhadap peluang rumah tangga petani untuk tahan pangan dengan menganggap variabel lain konstan. Hal itu terjadi karena beberapa anggota keluarga petani bekerja menjadi buruh harian lepas, laden tukang, penjahit, dan lainlain sehingga penghasilanya tidak menentu atau tidak dapat dipastikan. Selain itu beberapa dari anggota keluarga petani di Desa Timbulharjo masih belum bekerja atau masih sekolah sehingga belum menghasilkan pendapatan.

\section{f. Kepemilikan Simpanan Tabungan (X6)} Hipotesis :

Ho: Tidak ada pengaruh kepemilikan simpanan tabungan terhadap ketahanan pangan.

Ha: Ada pengaruh kepemilikan simpanan tabungan terhadap ketahanan pangan.
Dari hasil analisis variabel kepemilikan simpanan tabungan nilai signifikansi sebesar 0,378>0,05 sehingga menerima Ho. Sehingga, tidak ada pengaruh kepemilikan simpanan tabungan terhadap tingkat ketahanan pangan rumah tangga petani di Desa Timbulharjo, Sewon, Bantul.

Hasil penelitian ini sejalan dengan hasil penelitian yang diperoleh oleh (Supriyanto, 2014) yang menyatakan bahwa kepemilikan simpanan tabungan mempunyai tidak ada pengaruh terhadap peluang rumah tangga petani untuk tahan pangan dengan menganggap variabel lain konstan. Hal ini disebabkan karena masih rendahnya pendapatan masyarakat Desa Timbulharjo sebagai faktor penyebab rendahnya masyarakat belum dapat menabung, karena pendapatanya hanya cukup untuk memenuhi kehidupan sehari-hari. Selain itu sebagian besar tabungan rumah tangga petani di Desa Timbulharjo selain berupa hewan ternak (ayam, bebek, kambing, sapi). Ketika para petani membutuhkan uang untuk biaya sekolah anak ataupun biaya lainya mereka bisa menjual hewan ternaknya sesuai dengan kebutuhannya.

\section{Uji Apriori Teoritik}

Tabel 6. Uji Apriori Teoritik

\begin{tabular}{lccc}
\hline Variabel & Hipotesis & Hasil & Keterangan \\
\hline Pendapatan & + & + & Sesuai \\
\hline $\begin{array}{l}\text { Pendidikan } \\
\text { Kepala Keluarga }\end{array}$ & + & + & Sesuai \\
\hline $\begin{array}{l}\text { Usia Kepala } \\
\text { Keluarga }\end{array}$ & - & - & Sesuai \\
\hline $\begin{array}{l}\text { Status } \\
\text { Perkawinan }\end{array}$ & $-/+$ & + & Sesuai \\
\hline $\begin{array}{l}\text { Jumlah Anggota } \\
\text { Keluarga }\end{array}$ & $-/+$ & - & Sesuai \\
\hline $\begin{array}{l}\text { Kepemilikan } \\
\text { Simpanan } \\
\text { Tabungan }\end{array}$ & $-/+$ & - & Sesuai \\
\hline
\end{tabular}

Sumber : Data Primer Tahun 2017

Pengujian apriori teoritik dilakukan dengan cara membandingkan kesesuaian tanda diantara variabel estimasi yang digunakan dengan teori ekonomi. Apabila telah sesuai maka dapat dikatakan model yang diestimasi telah lolos dalam uji ini. Tanda positif menunjukan variabel independen searah dengan variabel dependen, sedangkan tanda negatif menunjukan arah yang berlawanan. 
Tabel 9 menunjukan bahwa hasil penelitian ini sesuai dengan hipotesis yang telah disusun berdasarkan pertimbangan-pertimbangan penelitian terdahuu yang relevan. Variabel pendapatan, pendidikan kepala keluarga, status perkawinan searah dengan ketahanan pangan, sedangkan variabel usia kepala keluarga, jumlah anggota keluarga dan kepemilikan tabungan berlawanan dengan ketahanan pangan.

\section{SIMPULAN}

\section{Simpulan}

Berdasarkan hasil penelitian yang telah dilakukan, maka dapat disimpulkan beberapa hal di bawah ini :

1. Hasil analisis variabel pendapatan nilai signifikansi sebesar 0,005 $<0,05$ sehingga Ho ditolak. Jadi ada pengaruh pendapatan terhadap tingkat ketahanan pangan rumah tangga petani di Desa Timbulharjo, Sewon, Bantul.

2. Hasil analisis variabel pendidikan kepala keluarga nilai signifikansi sebesar 0,014 < 0,05 sehingga Ho ditolak. Jadi ada pengaruh pendidikan kepala keluarga terhadap tingkat ketahanan pangan rumah tangga petani di Desa Timbulharjo, Sewon, Bantul.

3. Hasil analisis variabel usia kepala keluarga nilai signifikansi sebesar 0,896 > 0,05 sehingga Ho ditolak. Jadi tidak ada pengaruh usia kepala terhadap tingkat ketahanan pangan rumah tangga petani di Desa Timbulharjo, Sewon, Bantul.

4. Hasil analisis variabel status perkawinan nilai signifikansi sebesar $0,136>0,05$ sehingga Ho ditolak. Sehingga, tidak ada pengaruh status perkawinan terhadap tingkat ketahanan pangan rumah tangga petani di Desa Timbulharjo, Sewon, Bantul.

5. Hasil analisis variabel jumlah anggota keluarga nilai signifikansi sebesar 0,020 < 0,05 sehingga Ho ditolak. Sehingga, ada pengaruh jumlah anggota keluarga terhadap tingkat ketahanan pangan rumah tangga petani di Desa Timbulharjo, Sewon, Bantul.

6. Hasil analisis variabel kepemilikan simpanan tabungan nilai signifikansi sebesar 0,378 > 0,05 sehingga Ho ditolak. Sehingga, tidak ada pengaruh kepemilikan simpanan tabungan terhadap tingkat ketahanan pangan rumah tangga petani di Desa Timbulharjo, Sewon, Bantul.

7. Secara simultan, pendapatan, pendidikan kepala keluarga, usia kepala keluarga, status perkawinan, jumlah anggota keluarga dan kepemilikan simpanan tabungan berpengaruh terhadap ketahanan pangan rumahtangga petani di Desa Timbulharjo, Sewon, Bantul.

\section{DAFTAR PUSTAKA}

Hasan, 2000. Pokok-Pokok Materi Metodologi Penelitian Dan Aplikasinya. Jakarta: Ghalia Indonesia.

Rosiana, Pratiwi, 2016. Analisis Tingkat Ketahanan Pangan Rumah Tangga Petani Di Desa Kenongorejo Kecamatan Bringin Kabupaten Ngawi. Swara Bhumi. Vol 4, No 02.

Sugiyono, 2009. Metode Penelitian Bisnis. Alfabeta. Bandung.

Supriyanto, Teguh. 2014 di Kecamatan Karanggede Kabupaten Boyolali. "Analisis tingkat ketahanan pangan rumah tangga tani Desa Mandiri Pangan". Skripsi. Surakarta: Universitas Sebelas Maret.

Susilowati, Heni. 2014. Faktor-Faktor Yang Mempengaruhi Ketahanan Pangan Rumah Tangga Miskin di Kecamatan Srandakan Bantul. Skripsi. Yogyakarta: Universitas Negeri Yogyakarta.

Undang-Undang Ketahanan Pangan No 18 tahun 2012: Ketentuan Umum Pasal 1 ayat (4). Didapatkan:

http://jdih.bpk.go.id/wpcontent/uploads/2012/03/UU-Nomor18-Tahun-2012.pdf 